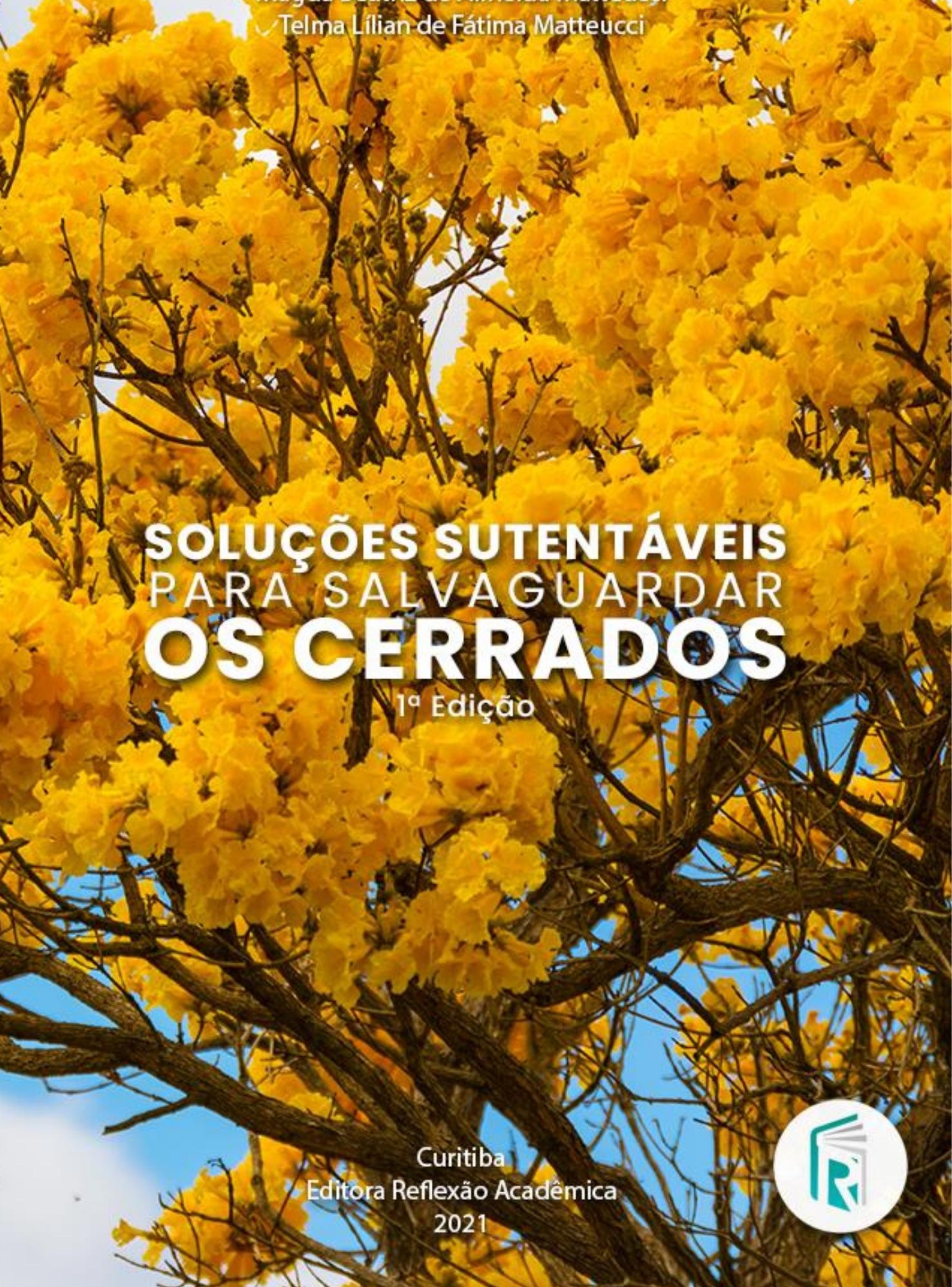


Magda Beatriz de Almeida Matteucci

Telma Lilian de Fátima Matteucci

\section{Soluções sustentáveis para salvaguardar os cerrados}

$1^{\circ}$ Edição

Curitiba

2021 
Copyright (C Editora Reflexão Acadêmica

Copyright do Texto (C) 2021 A Autora

Copyright da Edição @ 2021 Editora Reflexão Acadêmica

Diagramação: Sabrina Binotti

Revisão: As Autoras

O conteúdo dos artigos e seus dados em sua forma, correção e confiabilidade são de responsabilidade exclusiva da autora. Permitido o download da obra e o compartilhamento desde que sejam atribuídos créditos a autora, mas sem a possibilidade de alterá-la de nenhuma forma ou utilizá-la para fins comerciais.

\section{Conselho Editorial:}

Profa. Msc. Adriana Karin Goelzer Leinig, Universidade Federal do Paraná, Brasil.

Prof. Dr. Anderson Catapan, Universidade Tecnológica Federal do Paraná, Brasil. 


\begin{tabular}{|l}
\hline Dados Internacionais de Catalogação na Publicação (CIP) \\
\hline M435s Matteucci, Magda Beatriz de Almeida \\
Soluções sustentáveis para salvaguardar os cerrados / \\
Magda Beatriz de Almeida Matteucci, Telma Lilian de \\
Fátima Matteucci. Curitiba: Editora Reflexão \\
Acadêmica, 2021. \\
71 p. \\
Formato: PDF \\
Requisitos de sistema: Adobe Acrobat Reader \\
Modo de acesso: World Wide Web \\
Inclui: Bibliografia \\
ISBN: 978-65-995551-7-6 \\
DOI: doi.org/10.51497/reflex.0000152 \\
1. Soluções sustentáveis. 2. Cerrado. I. Matteucci, \\
Magda Beatriz de Almeida. II. Matteucci, Telma Lilian \\
de Fátima. III. Título.
\end{tabular}

\author{
Editora Reflexão Acadêmica \\ Curitiba - Paraná - Brasil \\ www.reflexaoacademica.com.br \\ contato@reflexaoacademica.com.br
}




\section{AUTORAS}

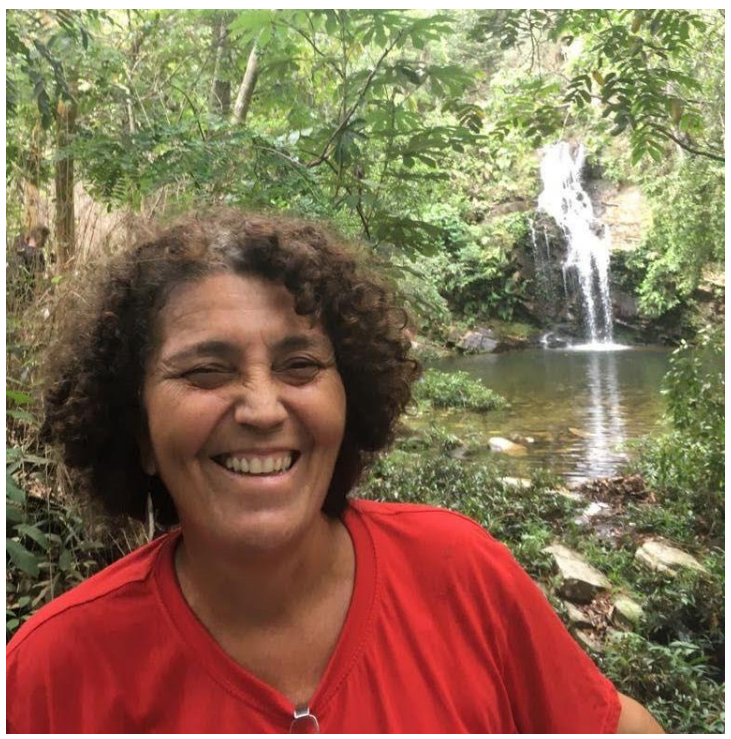

Magda Beatriz de Almeida Matteucci - É goianiense e graduada Engenheira Agrônoma pela Universidade Federal de Goiás. É considerada uma das precursoras da Agroecologia em Goiás ao propor um novo modelo de agricultura no artigo Agricultura Alternativa publicado no jornal O Popular em janeiro de 1989. Em junho deste mesmo ano, coordena o curso de Agricultura Alternativa, o marco referencial da Agroecologia em Goiás. A palestrante foi a renomada Profa. Ana Maria Primavesi

Sua carreira profissional como professora da Escola de Agronomia da UFG, sempre se pautou por um ensino voltado para uma agricultura em equilíbrio com o ambiente natural.

É especialista em Agricultura Tropical pela Universidade Federal Rural de Pernambuco, mestre em Agronomia pela Universidade Federal da Bahia e doutora 
em Desenvolvimento Sustentável - Gestão Ambiental pela Universidade de Brasília.

Possui um volume considerável de pesquisas sobre espécies nativas dos Cerrados, agroecologia, gestão e educação ambiental.

Contato: mbeatriz@ufg.br

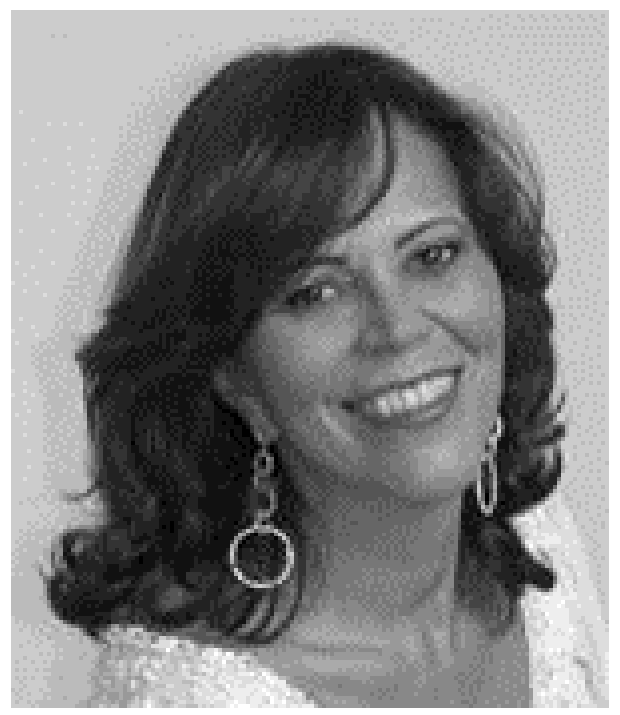

Telma Lilian de Fátima Matteucci - goianiense, graduada em Biblioteconomia pela Universidade Federal de Goiás, tecnóloga em Design de Interiores e Pós Graduada em Lighting Designer pela Universidade Castelo Branco, tendo participado de inúmeras mostras de decoração no estado de Goiás.

Apaixonada pela natureza e pelo cerrado, paisagista amadora, especializou-se em Composição paisagística pela Uni Anhanguera e desde então vem desenvolvendo trabalhos especialmente com a divulgação das plantas nativas do cerrado na composição paisagística

Contato: telmamatteucci@gmail.com 


\section{SUMÁRIO}

CAPÍTULO 01

O extrativismo orientado

CAPÍTULO 02

A agroecologia

CAPÍTULO 03

O ecoturismo

CAPÍTULO 04

35

Arborização urbana com espécies nativas dos cerrados CAPÍTULO 05 51

Outras formas de aproveitamento ecômica e ambientalmente sustentáveis 


\section{APRESENTAÇÃO}

O Cerrado é uma formação vegetacional inexistente em qualquer outro lugar no planeta, é único e predominante na Região Centro Oeste do Brasil. É redundante afirmar que no Cerrado encontramos uma rica flora destacando-se entre as savanas do planeta. É o segundo bioma brasileiro em extensão ocupando entorno de um quarto do território do país. Nele encontra-se um terço da biodiversidade nacional e $5 \%$ da flora e fauna mundial. Grande parte da flora é endêmica o que significa ser de distribuição geográfica restrita, ou seja, existir somente neste bioma. Se as espécies desaparecerem é para sempre.

Economicamente se destaca como um representativo centro de produção de commodities como a soja, o milho e o boi. Essas atividades são conduzidas, via de regra, a custas da retirada da vegetação nativa exclusiva, o que ameaça este bioma de extinção. Ademais essas culturas têm raízes superficiais consequentemente quando as chuvas caem, a água não infiltra como deveria. Como efeito com o passar dos tempos, tem reduzida a capacidade de armazenar e de conduzir a água subterrânea para poços e minas, assim as nascentes decrescem, afetando o nível dos aquíferos o que compromete o ciclo hidrológico.

O avanço das atividades do agronegócio, eliminando a vegetação dos Cerrados pode, ainda, estar comprometendo a agricultura em suas diferentes formas de produção, a economia, a indústria e o meio ambiente, sobretudo por comprometer o fornecimento de água. Isso desconsiderando o abastecimento público. A água é vital para a vida humana e sua disponibilidade está umbilicalmente associada a presença da vegetação, de árvores. A água depende de árvores para completar seu ciclo. De mais a mais, muitos ignoram que numerosas espécies dos Cerrados fornecem frutos, sementes ou palmitos saborosos e nutritivos com possibilidade de serem 
economicamente aproveitados seja na indústria alimentícia ou farmacêutica, ou ainda fornecendo frutos in natura como também madeiras ou oferecendo proteção ambiental ou é fonte de alimento para várias espécies de animais silvestres.

Os frutos como o araticum (Annona crassiflora Mart.), o pequi (Caryocar brasiliense Camb.), a cagaita (Eugenia dysenterica DC.), o jatobá (Hymenaea stigonocarpa Mart. Ex Hayne), o baru (Dipteryx alata Vog.), a mangaba (Hancornia speciosa Gomes), o buriti (Mauritia flexuosa L), a guariroba (Syagrus oleraceae L.), entre outras, constituem fontes importantes de fibras, proteínas, vitaminas, minerais, ácidos graxos saturados e insaturados presentes em polpas e sementes.

Ademais as espécies nativas possuem características sensoriais como cor, sabor e aroma peculiares e penetrantes. Várias plantas são utilizadas em virtude destes atrativos como condimento a exemplo da pimenta-demacaco (Xylopia aromática); para aromatizar como os frutos do murici (Byrsonima crassifolia), na cachaça ou da amburana (Amburana claudii Schwacke \&Taub), aromatizante para o fumo ou ainda a mama-cadela (Brosimum gaudichaudii Tréc), cujas raízes também são usadas como aromatizante de tabaco para cachimbo ou cigarro de palha ou artesanal.

Concomitantemente muitas espécies além dos frutos fornecem madeiras. Estas madeiras são detentoras de particularidades como cor, textura, dureza e fibras de desenhos exóticos, passíveis de atender a um nicho de mercado sofisticado como 0 de design de móveis, especialmente no mercado internacional.

Similarmente muitas de suas espécies são utilizadas para o fabrico de cosméticos comercializados nacional e internacionalmente, sendo exemplo o buriti. Contudo excetuando-se o pequi, a guariroba e o baru, os demais frutos do Cerrado são explorados apenas por populações tradicionais. 
O uso sustentável dos recursos naturais necessita combinar ações que proporcionem o desenvolvimento da região, o bem-estar social e a proteção da fauna e da flora. $E$, ainda, é fundamental como alternativa social e econômica de inclusão e geração de renda para os que dependem de recursos do bioma onde vivem.

Neste contexto essa publicação tem a primordial função de aglutinar informações sobre atividades que, de maneira sustentável, sejam a solução para o uso dos recursos naturais desse bioma sob a ótica sócioecológica e socioeconômica.

Neste sentido busca, de maneira acessível, apresentar ao público leitor algumas alternativas sustentáveis. Alternativas econômicas de baixo impacto ambiental que possam gerar renda conciliada com a conservação/preservação dos Cerrados. Soluções consideradas tecnologias leves em substituição àquelas empregadas pelo agronegócio que vêm pondo em risco a continuidade deste bioma. Enfim, a valorizar os Cerrados como ambiente de vida e de sobrevivência.

Assim serão propostas estratégias, atitudes ou atividades que postas em prática, contribuam para a conservação dos Cerrados, ainda por ser o bioma essencial para o ciclo hidrológico no Brasil Central.

As atividades propostas são o extrativismo orientado, o ecoturismo, a agricultura sustentável: agroecologia e a arborização urbana com espécies nativas dos Cerrados. Além de elencar outras possibilidades como a criação de animais silvestres e a apicultura.

Essas são alguns entre outros meios de garantir a conservação/preservação deste bioma essencial no ciclo hidrológico e um símbolo cultural goiano, especialmente na gastronomia. 


\section{CAPÍTULO 01 \\ O EXTRATIVISMO ORIENTADO}

O extrativismo é a forma mais antiga de utilização da natureza pela espécie humana. Os recursos naturais de qualquer natureza são historicamente objeto de coleta. Retira-se da natureza o que necessita sem terem sidos cultivados. Essa atividade conduzida com bom senso, prudencia, conhecimento e técnica apropriada contribui positivamente para o meio ambiente, na conservação dos recursos naturais do bioma enquanto gera renda.

Ao contrário de se derrubar a floresta faz-se a extração sustentável dos frutos dessa floresta. E, dependendo da região e do que se extraí, obtém-se uma renda muito maior do que a exploração da área com culturas de exportação. E, acresce-se que a presença de árvores, contribui para uma melhor distribuição de chuvas entre outros benefícios ambientais.

O extrativismo faz-se de espécies com potencial de usos tais como frutos comestíveis, palmeiras ornamentais e fornecedoras de castanhas, espécies medicinais, tintoriais, madeireiras, ornamentais, melíferas, oleaginosas, 
forrageiras entre muitas das formas de usos. As nativas do Cerrado são espécies polivalentes possuindo diversas formas de usos. Podem servir de alimentos com seus frutos e concomitantemente fornecerem madeiras, recursos medicinais, tintoriais, ou ornamentais entre outros.

Os alimentos são essenciais para a vida e podem se configurar como um símbolo cultural. A alimentação é considerada como uma prática de construção da identidade de um grupo social, de uma nação. A culinária goiana, mineira e até em determinadas regiões baianas foram desenvolvidas com o emprego de ingredientes oriundos da flora brasileira e neste contexto via espécies nativas dos Cerrados. $\mathrm{Na}$ gastronomia nacional destacam-se como pratos exóticos da Região Centro Oeste aqueles preparados com o fruto do pequizeiro (Caryocar brasiliense Camb.) tais como o arroz com pequi, frango com pequi, feijão com pequi, ele puro e cozido com temperos.

$\mathrm{Na}$ gastronomia goiana prevalece o emprego de algumas outras espécies como a guariroba (Syagrus oleracea L.).

Destacaremos aquelas fornecedoras de frutos que são tradicionalmente consumidas em Goiás e, simultaneamente, elencando algumas altamente promissoras. Não sendo a intenção desta publicação indicar 
espécies a serem usadas ou processadas isto porque para cada situação cabe uma solução.

\subsection{Frutos comestíveis}

O consumo in natura e o processamento artesanal de frutos dos Cerrados fazem parte da cultura da população tradicional deste bioma. Entretanto, uma quantidade considerável de frutas nativas ainda não é utilizada para processamento ou são processadas de forma restrita, como é o caso, além de outros, do buriti (Mauritia flexuosa L.) e da macaúba (Acromia aculeata), que são ricos em carotenoides, provitamina $A$ e são encontrados basicamente na forma de doces e picolés. O processamento de frutos nativos dos Cerrados para exploração comercial e industrial restringe-se a apenas algumas espécies do bioma.

Os frutos podem ser consumidos in natura, ou ainda serem utilizados na produção de licores, sucos, geléias, doces ou conservas. As espécies de usos mais populares são: o pequi, o cajuzinho (Anacardium humile A.St.-Hil.), a cagaita (Eugenia dysenterica DC.), o jatobá (Hymenaea stigonocarpa Mart. Ex Hayne), o baru (Dipteryx alata Vog.), o puçá (Mouriri elliptica.), a mangaba (Hancornia speciosa Gomes), a mutamba (Guazuma ulmifolia Lam.); a gabiroba (Campomanesia pubescens), o jenipapo (Genipa americana 
L), o murici (Byrsonima crassifolia), o araticum (Annona crassiflora Mart.), a marmelada (Alibertia edulis (Rich.) A.Rich.), a guapeva (Pouteria torta (Mart.) Radlk.), o bacopari (Garcinia gardneriana (Planch. \& Triana) Zappi.). Entre outras espécies.

Alguns exemplos e a forma de processamento são aqui elencados como forma de destacar as múltiplas oportunidades de explorá-los de maneira sustentável. E assim fazendo, contribuindo para a perpetuação das espécies nativas. Isto considerando que toda espécie que a humanidade vislumbrou como aproveitável em suas múltiplas formas de aproveitamento, não entrou em extinção.

O pequi se destaca na cultura do Centro-Oeste brasileiro, talvez o que apresente as mais numerosas formas de processamento artesanal ou industrial. Do fruto retira-se uma castanha e da polpa fabrica-se shampoo; condicionador capilar; conserva; creme; doce; farinha; licor; molho; óleo; picolé; polpa; sabonete; sorvete entre outras.

O jatobá é o fruto de outra árvore nativa do Cerrado que oferece um número expressivo de múltiplos usos por populações tradicionais deste bioma. Da polpa do fruto é feita uma farinha utilizada em receitas de biscoitos, bolos, pães, doces, picolés, suco, vinho e sorvetes. 
O baru, fruto do baruzeiro é a castanha do Cerrado. Saborosa e nutritiva além dos benefícios a saúde substitui o amendoim na elaboração de pratos populares como o pé de moleque e a paçoquinha e também é empregada no fabrico de rapadura, barra de proteína, doces, pães, cachaça, licor, molho pesto entre outros.

A mangaba fruto da mangabeira tem propriedades terapêuticas, todavia o que destaca essa fruta do Cerrado e de outros biomas é o sabor. Desta fruta obtêm-se suco, geleia; picolé; sorvete; vinhos; licor entre outros.

A cagaita é popularmente conhecida pelo efeito laxante de seus frutos. São empregados no fabrico de doces, geleias, licor, picolé, sorvete, sucos, entre outros.

$O$ jenipapo fruto do jenipapeiro era conhecido e utilizado por índios guaranis quando aqui aportaram os colonizadores portugueses. Eles o utilizavam tanto para o consumo como para pintarem seus corpos. Com propriedades terapêuticas comprovadas pela ciência esse fruto é utilizado para fabricar um dos mais conhecidos e apreciados licores. Empregado ainda como matéria prima de um doce cristalizado de sabor exótico, de compota, refresco, suco, vinho, vinagre e xarope. Os frutos do muricizeiro são culturalmente empregados para aromatizar a cachaça, fazer compota, licor, picolé, pinga, sorvete, entre outras. 
O fruto dessa palmeira, o buriti, é processado cultural e industrialmente fornecendo condicionador capilar, creme hidratante, doce muito apreciado, geleia, picolé, suco, sorvete, sabonete, vinho entre outros. O óleo da polpa do fruto de buriti também pode ser usado para fabricar protetor solar. Da castanha ainda se retira o óleo ou faz-se uma paçoca. Dentre as múltiplas funções dessa palmeira do Cerrado ela ainda é detentora de potencial paisagístico reconhecido, todavia pouco empregado.

Os exemplos mencionados explicitam as múltiplas finalidades de uma flora pouco viabilizada economicamente e capaz de atender mercados exóticos ou mesmo populares.

\subsection{Palmeiras ornamentais e fornecedoras de castanhas}

Planta símbolo e identidade das regiões tropicais, a família das palmeiras possui inúmeras espécies nos Cerrados. São reconhecidas, sobretudo pelo fornecimento de seus frutos muito mais do que pelo seu emprego em paisagismo. As que se sobressaem são: buriti (Mauritia flexuosa L), guariroba (Syagrus oleraceae L.), catolé (Syagrus comosa (Mart.) Mart.), Jerivá (Syagrus romanzoffiana), bacabá (Oneocarpus bacaba Mart.), indaiá (Attalea dubia (Mart.) Burret), macaúba (Acromia 
aculeata) e bacuri Scheelea phalerata (Mart. ex Spreng.) Burret entre outras.

As raízes das palmeiras podem proteger o solo, são raízes fasciculadas e $80 \%$ se estendem em um raio de 2 metros e atingem profundidade de até $40 \mathrm{~cm}$ em busca de água. Essa característica oferece resistência as palmeiras e favorece a manutenção da água no bioma. Da polpa dos frutos é possível fabricar uma diversidade de alimentos derivados, como sorvetes, geleias, licores e o vinho. E todas as citadas possuem características que as indicam para uso em paisagismo.

Dentre as palmeiras cumpre destacar a guariroba que fornece um palmito amargo característica impar desta espécie, muito apreciado e tradicionalmente utilizado em iguarias regionais, especialmente nos Estados de Goiás e Minas Gerais.

Ainda uma espécie endêmica que está sob pressões que a colocam em risco de extinção que é o coquinho azedo, a Butia capitata (Mart.) Becc. Os desmatamentos e o extrativismo descontrolados estão colocando em risco esta que é uma palmeira de rara beleza e porte adequado ao paisagismo.

\subsection{Espécies medicinais}


A cultura popular sempre reconheceu e valorizou a utilização de ervas medicinais no Brasil. O saber popular, a tradição oral conservou o valor medicinal de muitas espécies da flora nativa. O que também aconteceu com as plantas do Cerrado. Contudo é necessário saber que a espécie pode também apresentar toxicidade, o remédio para um pode ser tóxico para outro. A forma mais comum de consumir plantas na medicina popular é pelo seu chá, feito a partir de suas folhas, casca ou raiz quando secas ou frescas. Um conhecimento essencial é qual parte da planta deve ser utilizada, folha, (fresca ou seca), talo, flores, raiz, semente, baga ou fruto.

As propriedades terapêuticas, ou medicinais de uma planta, são decorrentes dos princípios ativos que ela dispõe. A medicina popular emprega muitas das espécies nativas dos Cerrados. Algumas delas como faveira (Dimorphandra mollis) se extrai uma substância denominada rutina; do barbatimão - Stryphnodendron obovatum, um princípio ativo cicatrizante; a copaíba - Copaifera langsdorffii; uma substância com ação anti-inflamatória, a sucupira (Pterodon pubescens Benth), a poaia (Hybanthus ipecacuanha (L.) Saill.) utilizada para tratar doenças respiratórias. O mulungu (Erythrina mulungu Mart. ex Benth.) tem ação na insônia e o 
estresse. Isso acontece por sua ação sedativa antidepressiva e, por seu efeito tranquilizante, também age nos casos de síndrome do pânico, compulsões diversas, histeria e neurose.

Essas citadas têm seus princípios ativos confirmados pela medicina científica de acordo com as recomendações da Organização Mundial de Saúde. Muitos medicamentos são preparados em laboratório de fitoterápicos empregando princípios ativos destas espécies e de outras mais.

Muitas outras plantas têm emprego na medicina popular não sendo o propósito desta publicação. Contudo cumpre destacar o poder anti-inflamatório do fruto do baruzeiro como também a recomendação terapêutica do uso do jenipapo. Essa última espécie tem aplicação em funções digestivas e indicações de uso como amenizante dos efeitos e das reações do tratamento químico do câncer.

Também a sucupira cuja semente por muitos é usada para infecções da garganta e como anti-inflamatória, antirreumática, cicatrizante, antimicrobiana.

Algumas além de medicinais são fornecedoras de frutos comestíveis para consumo in natura, produção de licores, sucos, geleias, doces ou conservas; como o baru, o jatobá, o jenipapo e o pequi ou também podem ser aproveitadas no fornecimento de madeira para as diversas 
aplicações na construção civil, naval entre outras; como o guatambu (Aspidosperma macrocarpon Mart.) cuja casca é utilizada na medicina popular num chá digestivo, ou mesmo a sucupira em paisagismo em virtude de sua beleza e fornecedora de uma madeira de desing muito apreciado.

Outras fornecem flores ou frutos aproveitados para confeccionar arranjos florais e enfeites e ainda espécies que também podem ser empregadas em arborização urbana como é o caso da pata de vaca (Bauhinia forficata) de ação antioxidante, analgésica, diurética, laxante, purgativa, hipocolesterolemiante e vermífuga.

\subsection{Espécies tintoriais /aromáticas}

Algumas espécies são historicamente empregadas para valorizar o sabor ou mesmo o aroma de alimentos, perfumar as casas e com consumo na medicina popular.

Os múltiplos usos de espécies nativas do Cerrado contemplam essas possibilidades, algumas são destacadas abaixo.

Amburana - Amburana cearenses. A cumarina das sementes é utilizada como aromatizante de tabacos, roupas e sabonetes e como repelente de insetos e traças. 


\section{Aroeira vermelha/pimenteira - Schinus}

terebinthifolius. A casca da madeira é utilizada para tingir rede.

Baru - Dipteryx alata. É usado em tabacaria, óleo extraído da amêndoa atua como aromatizante do fumo. A semente tem sabor semelhante ao do amendoim e pode ser consumida sob a forma natural ou torrada.

Buriti - Mauritia flexuosa L. A cor intensa do óleo de buriti deve-se ao elevado teor de carotenos totais, o que lhe confere a característica de um corante natural.

Ipê amarelo - Tabebuia aurea. A casca quando fervida fornece um corante amarelo empregado para colorir fios de algodão usados em tecelagem

Jenipapo - Genipa americana L. Do sumo do fruto verde, se extrai uma tinta com a qual se pode pintar a pele, paredes, cerâmica entre outros. Também é uma fonte natural de corante azul utilizado na indústria alimentícia.

Mama-cadela - Brosimum gaudichaudii. A casca da raiz, depois de seca e triturada, pode ser usada para aromatizar o tabaco para cachimbo ou cigarro.

Manacá - Spiranthera odoratissima. As flores secas podem ser usadas como aromatizantes do chá preto, como sucedâneo. 
Murici - Byrsonima verbascifolia. Desta planta se extrai um corante preto utilizado na indústria de tecidos, conferindo cor cinzenta ao algodão.

Mutamba - Guazuma ulmifolia. As sementes produzem um óleo aromático com emprego em perfumaria.

Caparosa do campo -Neea theifera Oerst. As folhas produzem uma tinta de cor preta utilizada pelo povo para tingir tecidos.

Pau-marfim - Agonandra brasiliensis. A raiz amarga é utilizada para dar sabor à cerveja e torná-la amarelada sendo, portanto, corante e aromatizante.

Pau-Pombo - Tapirira guianensis. Produz um óleo aromático com aroma de limão.

Pimenta de macaco - Xylopia aromática. Os frutos substituem a pimenta-do-reino. Das flores extrai-se um óleo aromático usado em perfumaria.

Tinteiro/cervejinha do campo - Arrabidea brachipoda. Além do seu vasto emprego na fitoterapia, toda planta produz uma tinta de coloração escura utilizada no tingimento de tecidos.

\subsection{CONSIDERAÇÕES FINAIS}

Muito embora o propósito deste capítulo seja abordar espécies apropriadas ao extrativismo, cumpre ressaltar que 
as mesmas podem ser cultivadas em plantios comerciais, em agroecossistemas, ou ainda em permacultura, também conhecida pelo termo Sistemas Agroflorestais- SAF, um modelo de agricultura sustentável.

Os plantios podem ser feitos em desenhos que, empregando o princípio de plantas companheiras, distribua espécies como, por exemplo, plantar em arranjo o pequi, o baru e a mangaba. Entre outras muitas possibilidades de arranjos biodiversos dentro da fitossociologia. Neste contexto, a população de plantas de cada espécie deve obedecer a uma distribuição espacial aleatória nunca linear. 


\section{CAPÍTULO 02 A AGROECOLOGIA}

A Agroecologia é uma abordagem da agricultura que integra diversos aspectos agronômicos, ecológicos e socioeconômicos, na avaliação dos efeitos das técnicas agrícolas sobre a produção de alimentos e na sociedade como um todo. É a base científico-tecnológica para uma agricultura sustentável, uma vez que a nela a agricultura é vista como um sistema vivo e complexo, inserida na natureza rica em diversidade, com vários tipos de plantas, animais, microrganismos, minerais e infinitas formas de relação entre estes e outros habitantes do planeta Terra. Literalmente, a agroecologia é a base científico-tecnológica para uma agricultura sustentável.

É uma nova agricultura, capaz de trazer benefícios aos seres humanos e ao meio ambiente como um todo, afastando-nos da orientação dominante de uma agricultura intensiva em capital, energia e recursos naturais não renováveis, agressiva ao meio ambiente, excludente do ponto de vista social e causadora de dependência econômica. 
Em seus diversos modelos, as plantas podem ser cultivadas em várias disposições de tempo e espaço, melhorando assim, o uso de recursos e ressaltando as características de auto sustentação e de conservação de recursos do sistema, além de promover sua estabilidade, tanto em termos de fertilidade de solo, controle de pragas, bem como atuando na diversificação da renda do agricultor.

Em contrapartida a agricultura químicamotomecanizada fundamenta-se, principalmente, no monocultivo. A simplificação imposta ao sistema, através da ocupação de extensas áreas com uma só espécie de planta, favorece desequilíbrios. Aparecem então as doenças e as pragas e com elas a necessidade da introdução de energia como forma de promover o reequilíbrio do sistema. Para solucionar esse problema, a agricultura convencional recorre a tática da aplicação de produtos químicos, os agrotóxicos, que como forma de controle é extremamente impactante dado que esses produtos, em sua maioria, exterminam indistintamente os insetos e seus predadores, contaminam o meio ambiente e comprometem a saúde humana.

$\mathrm{Na}$ combinação de métodos para uma agricultura estável é necessário o conhecimento das bases ecológicas em que estão fundamentados os agroecossistemas. Para produzir sem destruir, algumas práticas podem ser 
adotadas. Assim é que ao princípio da sequência de cultivos, pode aliar-se os da alelopatia-plantas companheiras- na busca do controle de insetos-pragas e na manutenção ou aumento da produtividade.

Neste contexto a ciência que aponta para uma agricultura sustentável é a agroecologia por que apresenta uma série de princípios, conceitos e metodologias para estudar, analisar, dirigir, desenhar e avaliar agroecossistemas, com 0 propósito de permitir a implantação e o desenvolvimento de estilos de agricultura com maiores níveis de sustentabilidade.

O modelo agroecológico é potencializador da multifuncionalidade da propriedade possibilitando a produção, lazer, turismo rural, agroindústria e outras atividades.

Em agroecologia prevalece a eficiência produtiva 0 que promove a longevidade da capacidade produtiva, fomenta o uso de recursos renováveis localmente acessíveis - que favorece uma baixa dependência de insumos comerciais, faz o resgate e a valorização dos saberes e da cultura local.

As práticas dentro dessa ciência contribuem para a conservação dos recursos naturais e a proteção da biodiversidade ao privilegiar práticas conservacionistas que 
recuperam e elevam a qualidade do solo e da água, além de impedir a contaminação de mananciais, leitos de rios, lençóis freáticos por sustâncias químicas. Por, sobretudo, utilizar a diversificação da produção- policultivos. A diversificação além de promover a estabilidade, tanto em termos de fertilidade de solo quanto de controle de pragas e doenças, favorece ainda a diversificação da renda do agricultor.

A rotação e consorciação de culturas, a separação de áreas para pousio e a formação de faixas de mato entre os talhões são práticas fundamentais na manutenção da diversidade do sistema. O aumento da biodiversidade favorece as interações entre as espécies evitando pragas e doenças e é fundamental na formação do solo. A diversidade de culturas é o uso mais completo de um ambiente.

E, com práticas sustentáveis, protege a saúde de quem consome seus produtos que são livres de insumos como agrotóxicos e adubos solúveis. O procedimento contrário a agricultura convencional que se apoia no petróleo como insumo de agrotóxicos e fertilizantes e é a base para a intensa mecanização que a caracteriza. E, sobretudo, a agroecologia economiza energia. Em resumo, basicamente 
os princípios norteadores para se produzir de forma sustentável são os seguintes:

1) Ter como meta a diversidade de culturas ou atividades, utilizar o maior número de elementos da natureza e evitar a monocultura e buscar a integração das atividades na propriedade;

2) Utilizar variedades e raças adaptadas;

3) O solo é o foco, a planta é a consequência. Dessa maneira nutrir e equilibrar o solo e não a planta. Entendendo que o solo tem vida e em solo vivo tem-se planta saudável e planta saudável leva a saúde de quem a consome;

4) A matéria orgânica é o segredo para o equilíbrio nutricional e a diversidade dos microrganismos benéficos do solo;

5) Manter o solo sempre coberto seja com plantios ou com mato;

6) Aproveitar ao máximo os recursos locais. Reaproveitando e reciclando, dentro das possibilidades, os recursos na propriedade e na produção, principalmente água, energia e resíduos. Todos os produtos sejam de origem vegetal ou animal devem ter origem na propriedade, serem produzidos dentro da propriedade;

7) Trabalhar com a rentabilidade com responsabilidade, ou seja, com a otimização da produção, 
pensando sempre em processos contrariamente que em produtos.

A agroecologia é uma frondosa árvore que abriga em seus ramos modelos de agricultura com métodos e técnicas diferenciadas, todavia dentro das características de sustentabilidade que essa ciência exige. Um apanhado dos principais métodos produtivos está abaixo elencado.

\subsection{Agricultura natural Mokiti Okada}

O método privilegia a força do solo, torná-lo puro e limpo. Quanto mais puro é o solo, maior é a sua força para o desenvolvimento das plantas. A fertilização do solo consiste no fortalecimento de sua energia natural. Para fertiliza-lo utiliza de compostos vegetais, que conservam a pureza do solo e permitem a reciclagem dos nutrientes para 0 desenvolvimento das plantas. Não emprega produtos químicos ou esterco animal.

Somando-se aos aspectos que envolvem saúde e ecologia, o método de cultivo natural tem raízes em questões econômicas e sociais como todo modelo agroecológico. 


\subsection{Agricultura biodinâmica}

A Agricultura Biodinâmica é inseparável dos fundamentos Antroposóficos Esse modelo de agricultura busca transformar a fazenda num organismo agrícola, sanando os danos ambientais provocados pela Revolução Verde proporcionando a integração de várias atividades na propriedade, como hortas, pomares, criação de animais e áreas de florestas nativas. Utiliza minerais, esterco e plantas medicinais de modo homeopático, através dos preparados biodinâmicos promovendo assim a vitalização dos alimentos e fornecendo mais saúde ao consumidor. Acredita que a partir do cuidado com o solo a qualidade dos alimentos seja aprimorada.

A agricultura biodinâmica difunde a interação entre a produção animal e a produção vegetal, o respeito ao calendário biodinâmico, a utilização dos preparados biodinâmicos, obtenção do composto, plantação de cercas vivas, adubação verde, entre outras, possibilitando o manejo sustentável da propriedade.

A biodinâmica não é apenas uma atividade econômica e o agricultor biodinâmico preocupa-se em enriquecer os meios de produção para legá-los às gerações futuras. O faz buscando a cura da terra, o bem-estar animal 
e a sustentabilidade da propriedade agrícola. Para tanto utiliza do conhecimento dos ciclos cósmicos e suas relações com a natureza tendo por objetivo uma relação mais saudável entre campo e cidade, através da criação de condições para uma agricultura orientada no equilíbrio entre ambiente, produtor e consumidor.

\subsection{Permacultura}

Permacultura é uma palavra que foi cunhada para um sistema evolutivo integrado de espécies vegetais e animais. Perenes ou autoperpetuantes úteis aos seres humanos. Em essência, é um ecossistema agrícola completo, modelado sobre exemplos naturais existentes, contudo mais acessível sob a ótica de sua execução.

A permacultura considera que o ser humano é somente um componente da natureza, que está ligado aos outros elementos. E que a Terra é uma comunidade organicamente entrelaçada de plantas, animais $e$ microrganismos, sustentando outras formas de vida. A permacultura abrange todos os aspectos do nosso ser: o corpo, a mente, a família, nossa casa e o nosso relacionamento com a comunidade, com a natureza e com o mundo. 
O objetivo é a criação de sistemas que sejam ecologicamente corretos e economicamente viáveis; que supram suas próprias necessidades, não explorem ou poluam e que, assim, sejam sustentáveis a longo prazo.

A permacultura é baseada na observação de sistemas naturais, na sabedoria contida em sistemas produtivos tradicionais e no conhecimento moderno, científico e tecnológico. Embora baseada em modelos ecológicos positivos, a permacultura cria uma ecologia cultivada, que é projetada para produzir mais alimentação humana e animal do que seria encontrado naturalmente.

\subsubsection{Características Básicas}

1. É possível o uso da terra em pequena escala.

2. Uso da terra intensivo, e não extensivo.

3. Diversidade nas espécies de plantas, variedades, produtividade, microclima e habitat.

4. Prazo longo: um processo evolucionário abarcando várias gerações.

5. Os elementos integrantes do sistema são silvestres, adaptados ou pouco selecionados. Tanto animais como vegetais. 
6. Possibilita a integração de agricultura, pastoreio, reflorestamento, realizando uma verdadeira engenharia ecológica.

7. Adaptável a terras marginais, pantanosas, rochosas ou inclinadas, inadequadas a outros sistemas.

\subsection{Agricultuta orgânica}

Dentro da produção orgânica, os nutrientes são fornecidos às plantas através da compostagem de restos vegetais e animais, da aplicação de esterco de animal curado proveniente de locais que não tenham usado nenhum tipo de agrotóxico, antibiótico e metais tóxicos. Aplica-se ainda cinzas; restos culturais; vermicompostagem ou húmus de minhoca e biofertilizantes.

Outra fonte muito utilizada são os adubos verdes uma técnica em que se faz a adubação a partir dos restos de uma cultura que forneça especialmente nitrogênio tais como crotalárias, feijão de porco guandu, mucuna, milheto, nabo forrageiro entre outros

O sistema orgânico permite a adubação mineral cuja origem seja natural sendo os mais utilizados o calcário, pó de rocha, fosfatos naturais 
A produção orgânica atende a Lei 10.831 de 23 de dezembro de 2003, a instruções normativas como a Instrução Normativa 17/2014/MAPA como também a portarias como a Portaria, No.52 de 15 de março de 2021. Convém serem consultadas pois contém o que pode e o que não pode ser utilizado neste modelo de agricultura .

\subsection{Certificação}

Com o intuito de identificar e garantir a procedência e o processamento de um alimento orgânico e com isso poder comercializá-lo os produtores devem regularizar sua produção através da certificação. E para tal um documento deve emitido por uma certificadora credenciada autorizada de uma das formas a seguir:

a) Certificação Participativa-Participação dos produtores e consumidores na elaboração e verificação das normas de produção.

- Organismo Participativo de Avaliação da Conformidade (Opac).

- Organização de Controle Social.

b) Certificação por Auditoria. 


\section{CAPÍTULO 03 \\ O ECOTURISMO}

O ecoturismo é definido como sendo o turismo desenvolvido em localidades com potencial ecológico, de forma conservacionista, procurando conciliar a exploração turística com o meio ambiente, harmonizando as ações com a natureza, bem como oferecer aos turistas um contato íntimo com os recursos naturais e culturais da região, buscando a formação de uma consciência ecológica nacional. Essa atividade é uma modalidade considerada sustentável de turismo, uma fonte de renda para regiões que apresentam poucas possibilidades econômicas. Trata-se de uma atividade que beneficia populações sem alternativas de emprego e com risco de perder seus costumes culturais. E ser uma atividade aliada de ações conservacionistas ao fazer o uso sustentável de atrativos do meio ambiente e das manifestações culturais locais, com também ser uma ferramenta da educação ambiental.

É uma modalidade de turismo que se caracteriza pela valorização do patrimônio natural e cultural como foco de interesse do visitante e pela adequada interpretação ambiental desse patrimônio. É enfim um tipo de lazer que 
proporciona conhecimento. O lazer e a recreação como uma estratégia preservacionista dos Cerrados

Para que em uma localidade ou região haja o ecoturismo o principal requisito é apresentar belezas naturais e a primeira providência a ser adotada é, necessariamente, uma análise detalhada do local, verificando especialmente $o$ interesse que a região pode despertar no mercado, o que a diferencia das demais regiões e o que existe além do atrativo natural.

Outro aspecto fundamental é a existência de infraestrutura e serviços para se aproveitar o destino: tipo de hospedagem para o turista, meio de transporte, disponibilidade de guias ou condutores qualificados, o comércio local com lojas de artesanato entre outras.

Analisar qual o mercado mais promissor para essa localidade se local, regional, nacional, internacional, especializado como por exemplo, observação de animais, montanhismo, espeleologia ou uma combinação destes.

Os diferentes ecossistemas brasileiros oferecem inúmeras atrações desde belos campos à belas grutas, cavernas, rios cristalinos e outros belos cenários, sendo destacado nas regiões: floresta amazônica - nosso maior atrativo ecoturístico sendo a preferida por ecoturistas 
estrangeiros; mata atlântica; 8500 Km de litoral; Cerrado; pantanal; caatinga e campos.

Muito embora a riqueza do Cerrado seja sua flora e fauna ademais as bacias hidrográficas o destaque são as numerosas cachoeiras espalhadas nos quase 2 milhões de quilômetros quadrados que abrange esse bioma. Em especial, em Goiás, a riqueza de água é propiciada por ser o Estado banhado por grandes bacias hidrográficas a do rio Araguaia que divide Goiás com Mato Grosso; a do rio Tocantins ambas se encontram próximo ao Paralelo 5 e deságuam no Oceano Atlântico. E a do rio Paranaíba que nasce em Minas Gerais e divide Goiás com esse Estado. Quando encontra com o Rio Grande, forma o rio Paraná, que desemboca na Argentina.

A vegetação com decoradas por flores das mais variadas cores compõe um cenário incomum, especialmente nos meses de julho a setembro. O período do seco inverno goiano e o início da primavera. Ademais o Estado de Goiás se destaca por ser detentor de manifestações culturais carregadas de simbolismos religiosos atrelados a uma ruralidade que remonta os tempos da extração do ouro no Brasil.

Outro atrativo nesse ambiente é a fauna rica com espécies típicas do bioma, como onças, lobo guará, tatus, 
cervos, macacos, tamanduás, pacas, capivaras, antas, emas, e seriemas dentre tantas outras.

Todas essas características revelam o Cerrado como um ambiente a ser apreciado por ecoturistas e preservado por todos em seu patrimônio natural e cultural.

\subsection{Ecoturismo e as unidades de conservação (uc)}

As Unidades de Conservação representam territórios apropriados ao lazer na natureza por se tratar de áreas destinadas à proteção, por vezes, integral dos recursos naturais, admitindo-se, a depender da modalidade de UC, a visitação com objetivos turísticos, recreativos e educacionais. Neste sentido as Reservas Particulares do Patrimônio Natural - RPPNs, uma modalidade de UC de domínio privado, têm um importante e estratégico papel no cenário ambientalista, constituindo-se em espaços privilegiados, podendo tornar-se uma das soluções que contemplem a preservação conciliada com 0 desenvolvimento de atividades ecoturísticas.

Neste contexto Goiás é um estado privilegiado ocupando o quarto lugar no Brasil em áreas preservadas nesta modalidade de UC. As 73 RPPNs goianas cobrem uma área de 38222.26ha estando localizadas nos seguintes 
municípios: Pirenópolis (14), Alto Paraíso (12), Cavalcante (9); Cristalina (5) e Planaltina de Goiás (4), São João da Aliança (3), Cocalzinho (2), Cidade Ocidental (2); Corumbá de Goiás (2); Santo Antônio do Descoberto (2) Aruanã, Aporé, Britânia; Campestre de Goiás; Colinas do Sul, Formosa; Goiânia; Goianápolis, Hidrolândia, Itaberaí, Mineiros, Nova Crixás, Padre Bernardo, Paraúna, Trombas, Serranópolis, Terezópolis, todos com 1 (uma) unidade. Considerando que a área do Estado de Goiás é de 340086, km2, a porcentagem ocupada por esta modalidade de UC é, um valor que em uma primeira análise pode ser interpretado como uma fração pouco significativa ou numericamente inexpressiva, pois representa $0,11 \%$ do território goiano. Todavia um olhar comparativo entre os índices de áreas protegidas no Brasil e no Estado de Goiás, demonstra que o número e a área coberta por RPPNs são significativos e estratégicos, em especial, para a preservação dos Cerrados e para o desenvolvimento de atividades ecoturísticas.

\subsection{Ecoturismo em Goiás}

Todavia não apenas nas UCs o ecoturismo acontece em Goiás isto porque o potencial do Cerrado goiano é gigantesco, contudo, pouco aproveitado como em todo o 
Brasil. Pode-se citar algumas cidades com grande potencial como: Paraúna, Serranópolis, São Domingos, Caldas Novas, Caiapônia, Cristalina, Mineiros entre muitas outras como as elencadas abaixo. Como aquelas já consolidadas como Lagoa Santa, Alto Paraíso e Pirenópolis.

Em atenção a preservação do patrimônio cultural goiano uma cidade mereceria especial atenção, Pilar de Goiás. Localizada a 263 quilômetros de Goiânia pela BR153, Pilar de Goiás é uma das cidades mais antigas do Estado. Nasceu em 1736 de um quilombo, no auge da mineração do ouro. Os escravos foragidos encontraram neste um lugar para se esconderem e uma grande fonte de ouro com o qual compraram sua liberdade. De uma promessa a Nossa Senhora do Pilar para que surgisse água para o garimpo o então Quilombo de Papuã passou a assumir o nome atual. Em 10 anos, Pilar produziu o equivalente a todo o ouro extraído da província de Goiás em um século. Essa cidade possui um rico acervo cultural conservando o mesmo padrão arquitetônico da cidade de Goiás e Pirenópolis.

O conjunto arquitetônico e paisagístico foi tombado pelo Instituto do Patrimônio Histórico e Artístico Nacional (Iphan) em 1954. São duas igrejas e mais de 20 casarões centenários, alguns ostentam elementos únicos na 
arquitetura brasileira. Percorre-se todas as atrações históricas de Pilar a pé. São destaques:

Casa da Princesa ou Casa dos Dutra - Considerada a construção mais luxuosa do ciclo do ouro em Goiás, estudos e documentos da época comprovam que a Princesa Isabel nela viveu por aproximadamente 6 meses período referente ao auge de mineração.

Sinos de Pilar - Em número de três, os originais fabricados 1785 foram roubados e substituídos. São os maiores sinos já feitos para uma igreja em Goiás. Pesam, em média, $900 \mathrm{~kg}$ e quando dobravam seus sons podiam ser ouvidos a mais $6 \mathrm{~km}$ de distância. Estão localizados em um campanário construído após o desmoronamento da antiga igreja ao lado da nova Igreja Nossa Senhora de Pilar.

Igreja de Nossa Senhora do Pilar - a matriz- restam escombros, ruinas da maior Igreja da Província de Goiás.

Nossa Senhora das Mercês - o Erguida pela irmandade dos pardos é uma das três igrejas mais importantes do período no país, a única que guarda maior originalidade e integridade. Tombada pelo IPHAN como Patrimônio Histórico em 1980. Foi restaurada em 2019, mantendo sua originalidade.

Chafariz São José - construído 1745 remanescente dos três chafarizes que abasteciam a cidade. Contudo ainda continua em atividade. 
Prainha da Limeira - antiga lavanderia de roupa das escravas.

Grutas dos Escravos - As galerias das antigas minas de ouro de Papuã, abandonadas após o veio de ouro adentrar a camada de rocha de quartzo. Preservam um importante acervo do Quilombo de Papuã, localizado na reserva ambiental da cachoeira do Ogó.

Manifestação Cultural - Ainda, Pilar também mantém viva as Cavalhadas, tradição de 124 anos no município.

Inserida no Vale do São Patrício Pilar de Goiás tem uma vegetação típica do Cerrado, as formações de serras e as trilhas rústicas. Também são atrações naturais a Cachoeira do Ogó, cachoeira que já serviu como fonte de água para a cidade restando fragmentos da antiga tubulação e a Ponte de Pedra é uma sequência de cavernas e grotas por onde o rio Caiamar tem seu curso.

Muito embora com as possibilidades majoritariamente, culturais Pilar de Goiás recebe poucos ecoturistas. Esta constatação sugere que o ecoturista está mais interessado em atividades que, predominantemente traga emoções e ligações diretas com a natureza.

$\mathrm{Na}$ Tabela1 uma relação de cidades com potencial ecoturístico localizadas a uma distância menor que $300 \mathrm{~km}$ 
da capital e que sequer são conhecidas por se potencialmente ecoturísticas. Destaque para Anicuns em virtude de sua origem: ouro pelos bandeirantes e por ser detentora de13 pontos apropriados para ecoturismo além do Rio dos Bois e o Rio Turvo e Cocalzinho por ter em seu território a Caverna dos Ecos, o maior lago subterrâneo da América Latina

Tabela 1 -Cidades goianas com potencial ecoturístico

\begin{tabular}{|l|l|}
\hline Cidade & Distância de Goiânia- km \\
\hline Anicuns & 75 \\
\hline Aurilândia & 150 \\
\hline Buriti de Goiás & 151 \\
\hline Catalão & 159 \\
\hline Cocalzinho & 125 \\
\hline Corumbá & 110 \\
\hline Iporá & 216 \\
\hline Luziânia & 188 \\
\hline Montes Claros de Goiás & 266 \\
\hline Palmeiras de Goiás & 187 \\
\hline Pilar de Goiás & 235 \\
\hline Quirinópolis & 280 \\
\hline
\end{tabular}

Fonte: As autoras. 



\section{CAPÍTULO 04}

\section{ARBORIZAÇÃO URBANA COM ESPÉCIES NATIVAS DOS CERRADOS}

O desenvolvimento urbano favorece o fenômeno da formação de ilhas de calor nos centros das cidades, o que explica a necessidade da arborização de ruas e avenidas e congêneres. Os benefícios das árvores são inúmeros e entre eles a redução da temperatura do ambiente. Uma árvore em um ano resfria tal qual um ar condicionado em funcionamento contínuo. Ainda reduz os níveis de poluição sonora e atuam como filtro ambiental, reduzindo a poluição do ar. Uma árvore em um ano retira $28 \mathrm{~kg}$ de poluentes do ar. Ademais são responsáveis por humanizar, preservar a biodiversidade e embelezar o meio urbano, quebram a velocidade dos ventos, minimizam os impactos da chuva além de atrair pássaros para o meio urbano.

Este texto possui caráter informativo e busca trazer respaldo técnico para a execução das ações voltadas à arborização urbana. Tem como objetivo primordial provocar nos leitores o interesse pelo Cerrado em suas diferentes formas de aproveitamento. Neste caso enfocando as nativas ornamentais disponíveis e possíveis de emprego no meio 
urbano. A existência de remanescentes da vegetação do Cerrado pode estar comprometida pelo avanço de atividades econômicas. O emprego de parcela das plantas oriundas deste bioma via arborização urbana pode ser uma medida conservacionista independentemente da utilidade da espécie ou benefícios naturais que promove. É um direito per si da natureza.

O paisagismo com espécies exóticas contribuí para a uniformização da paisagem ao passo que utilizando as espécies nativas colabora com a conservação da flora local e reforça identidades regionais.

Um desafio da arborização urbana é a valorização da flora local e o desenvolvimento de pesquisas sobre o comportamento e adaptação de espécies nativas no ambiente urbano. A utilização de espécies do Cerrado para criar uma identidade ao paisagismo urbano e garantir a manutenção da biodiversidade e um trabalho que deve ser desenvolvido e incentivado pelo poder público das cidades.

A diversidade das árvores ornamentais nativas do Cerrado é expressiva e ainda que os galhos e folhas sejam rústicos as flores são de beleza e delicadeza acentuadas. Utilizá-las no paisagismo urbano reforça a cultura goiana e contribui na conservação de espécies nativas de interesse paisagístico. Ademais elas são adequadas às condições 
edafoclimáticas da região, fornecem alimentos à fauna, podem funcionar como porta sementes, serem utilizadas em programas de Educação Ambiental na vulgarização do Cerrado, entre outros aspectos que as torna atrativas.

Neste contexto é imprescindível incrementar pesquisas das espécies com potencial econômico e de grande plasticidade em especial abrangendo estudos sobre germoplasma, germinação, crescimento inicial e a produção em escala comercial. A diversidade de espécies e variedades morfológicas tornam bastante complexa suas identificações, o que dificulta a indicação de espécies.

Não obstante convém destacar que não é função desta publicação indicar espécies para cada uma das situações de usos num planejamento de paisagismo urbano. Visto que para tal é necessário ser um(a) profissional qualificado(a) capaz de identificar para cada situação qual espécie empregar. Vale ainda destacar que todas as espécies apresentam vantagens e desvantagens e que não só a estética ou a beleza de suas flores é o principal requisito para utilizá-las. O local de plantio é o principal determinante para a escolha da espécie a ser utilizada. Se existe fiação na calçada, se é uma avenida ou um parque são situações distintas e por isso é necessário um 
conhecimento especializado para planejar a distribuição de espécies no planejamento dos plantios.

4.1 Critério de escolha de espécies destinadas a uso em calçadas e avenidas

A escolha de espécies apropriadas para a arborização urbana necessita de critérios para se evitar danos no corpo social e/ou econômico. Existem várias condições exigidas de uma árvore para que possa ser utilizada no meio urbano sem acarretar inconvenientes. Devem-se observar características relacionadas ao modelo do sistema radicular, configuração do formato da copa, engalhamento, deiscência dos frutos e queda das folhas entre outros. A copa merece especial atenção em virtude de interferir na fiação, na visualização de sinalizações e de placas indicativas de trânsito e demais inconvenientes.

A partir da local rua ou avenida, com fiação aérea ou subterrânea são escolhidas as espécies adequadas. Alguns dos critérios a serem observados para que as árvores possam ser utilizadas sem provocar danos se destacam, entre outras: 
a) Resistência a pragas e doenças, para evitar o uso de produtos fitossanitários, desaconselhados em vias públicas;

b) Velocidade de desenvolvimento média para rápida para se recuperar rapidamente da ação de predadores ou de um acidente onde a poda drástica tenha sido a única alternativa exigida;

c) Não deve produzir frutos grandes;

d) Troncos e ramos devem ter lenho resistente para evitar a queda na via pública e também serem livres de espinhos;

e) Não conter princípios tóxicos ou de reações alérgicas;

f) Não necessitem de podas constantes e

g) A copa das árvores deve ter tamanhos adequados. Árvores com copa muito grande interfere na passagem de veículos e pedestres e fiação aérea. Evitar árvores com sistema radicular superficial que prejudicam a calçadas, as fundações dos prédios de muros e caem facilmente.

A espécie mais adequada a cada situação evita problemas com podas, interrupção no fornecimento de energia elétrica, escurecimento das vias o que reduz a segurança da população, favorece a limpeza pública entre outras vantagens. 
4.2 Potencial de espécies ornamentais do cerrado para arborização urbana

As possibilidades de escolha são numerosas há uma policromia acentuada nas espécies nativas. Uma gama de cores e tons que facilitam o paisagismo urbano utilizando plantas deste bioma. A escolha recai sobre o local de destinação, as vantagens e desvantagens de cada uma delas.

No procedimento é fundamental identificar quais espécies são recomendadas, procurar respeitar a memória da cidade com seus valores culturais e ambientais especialmente as condições de permeabilidade do solo. Ainda se a ação vai proporcionar conforto para os moradores, abrigo e alimento para a avifauna, sombreamento adequado, redução da poluição, da paisagem, contribuindo para a melhoria das condições urbanísticas e o equilíbrio estético proporcionado pela planta. Ademais calcular a proporção de uma arvore por habitante e empregar o princípio da diversidade biológica.

Neste sentido é imprescindível o planejamento da arborização urbana a ser implantado. Analisar o local onde as mudas serão plantadas considerando a largura das ruas e calçadas, que tipo de arborização, se viária, de parques ou 
praças, posição da rede elétrica, distância de postes, esquinas, existência de garagens entre outros.

\subsection{Vantagens das espécies nativas}

No contexto dos benefícios oferecidos nos processos ecológicos pode se elencar.

a) Contribuem para a conservação do patrimônio genético do Cerrado.

b) São ajustadas ao clima e aos solos, podendo ser mais tolerantes ou resistentes a pragas e doenças;

c) Em virtude da grande quantidade de espécies, permite escolha e variações de porte, formato da copa, cor e época de floração;

d) Servem como fontes de sementes para outros programas de arborização reflorestamento;

e) São fontes de alimento para a fauna, especialmente pássaros, contribuindo para sua conservação, que além de suas cores e canto, comem insetos nocivos às plantas;

f) Podem ser usadas na Educação Ambiental e para que a população conheça a flora nativa.

\subsection{Arborização de ruas e avenidas}

A arborização de vias públicas refere-se às árvores plantadas linearmente nas calçadas ao longo de vias e avenidas. É a vegetação mais próxima da população 
urbana. É dividida em áreas verdes- parques, bosques, praças e jardins e a arborização de vias públicas-ruas e avenidas.

Por avenida entende-se uma via urbana de maior relevância em uma cidade, constituída por uma ou duas vias, larga ou extensa. Esta pode ser ponto de ligação entre vias de bairros importantes e conectando os serviços da região.

Uma rua é conceituada como uma via pública urbana de livre circulação. Usualmente é ladeada por casas, prédios, lojas, empresas, muros ou jardins e no centro dessa via transitam veículos. Via de regra, numa rua encontram-se calçada ou calçadas destinadas ao trânsito de pedestres podendo ter instalações aéreas como fiação de eletricidade, internet ou de telefone. Ou ainda instalações subterrâneas de água, esgoto, telefonia entre outros. Essas instalações exigem tipos distintos de árvores em razão da profundidade e extensão de suas raízes e extensão e tipo de projeção das copas.

Em ruas largas com passeios largos sem fiação a recomendação é de árvore de porte médio a grande porque podem atingir o seu tamanho característico sem comprometer os equipamentos púbicos, dando sombra e melhorando a qualidade do ar e equilibrando a temperatura. 
Nas ruas largas com passeios largos com fiação de baixa tensão é recomendado espécies de porte médio, desde que conduzidos para não tocarem nos fios, através da poda dos galhos internos. Recomenda-se também árvores de galhos duros, evitando-se a movimentação com o vento e as interrupções na rede elétrica. Plantas de porte pequeno que não interfere na fiação também devem ser indicadas. Em locais que não existem problemas estruturais recomendamse árvores que forneçam sombra e flores indistintamente. Contudo resguardando-se a segurança do patrimônio físico e das pessoas que transitam pela via.

\subsection{Relação das espécies por porte}

Numerosas espécies são possíveis de serem utilizadas, algumas das quais são encontradas em cidades goianas, inclusive na capital, Goiânia. Nas cidades do interior há uma preferência por ipês, de todas as cores preferencialmente o amarelo. Esta a árvore símbolo do Brasil. São componentes do universo cultual do Cerrado, contudo seja qual for a cor, apresenta o inconveniente de perderem as folhas no período da seca, de julho a setembro, durante o florescimento. O período de desfolha é curto, no entanto prejudica o sombreamento essencial durante esse 
período. Na prática essa característica pouco interfere na escolha desta planta e o seu uso é muito das vezes correto ao ser colocado em praças, avenidas ou mesmo calçadas. Este último emprego é respeitando ou não a presença de fiação elétrica. Uma vez que o porte das espécies é diferenciado, pois a expressão fenotípica da maioria das árvores tende a ser diferente de quando estão no ambiente natural ou não. Normalmente tende a apresentar um porte menor quando o espaçamento é maior abrindo mais a copa. A sabedoria popular utiliza dos ipês em praças, avenidas ou calçadas sem fiação.

Dentre inúmeras espécies destacamos as que consideramos apropriadas e que podem ser utilizadas em calçadas desde que observados os critérios necessários e a legislação vigente ABNT-NBR 9050/94. São elas a pata de vaca, a quaresmeira, a saboneteira, o mulungu, o cego machado e o jacarandá mimoso.

Nome vulgar: Pata de vaca

Nome científico: Bauhinia forficata subsp forticata. Sinonímia: Bauhinia candicans Benth., Bauhinia aculeata Vell., Bauhinia brasiliensis Vogel

Floração: agos/set

Altura máxima de 6 a 12 metros de altura, mas raramente passando de 10 metros. 
Descrição: ornamental apreciada em áreas urbanas por suas belas e grandes flores. A madeira é moderadamente densa, de baixa durabilidade natural quando exposta ao tempo. As folhas são caducifólias e são empregadas na medicina popular no tratamento da diabete.

Nome vulgar: Mulungu

Nome científico: Erythrina verna

Floração: floresce entre julho e setembro. As inflorescências apresentam coloração que variam entre o laranja e o vermelho, com as flores reunidas em cachos no final dos galhos

Altura: medindo entre 10 a 20 metros de altura

Descrição: pioneira e de crescimento rápido, de porte arbóreo medindo entre 10 a 20 metros de altura, com presença de espinhos ao longo dos troncos jovens. Tem distribuição geográfica restrita, só existe no Brasil na Amazônia, no Cerrado e na Mata Atlântica, merecendo uma melhor atenção para evitar sua extinção. Tem uso fitoterápico como calmante.

Nome vulgar: Quaresmeira

Nome científico: Tibouchina granulosa

Floração: ocorre em dois períodos a depender do bioma: jan/abr e Jul/agos e possui flores róseas e roxas. 
Altura: porte geralmente é pequeno a médio, podendo atingir de 8 a 12 metros de altura.

Descrição: é uma pioneira. Muito utilizada em arborização por seu porte e beleza. O inconveniente é a fragilidade de seus ramos passíveis de quebra com a força dos ventos. Contudo seu sistema radicular não danifica calçadas.

Nome vulgar: Saboneteira

Nome científico: Sapindus saponaria L.

Floração: Abril-Junho. flores brancas dispostas em panículas

Altura: 5 a 10 metros de altura

Descrição: Ornamental, de copa arredondada, folhas perenes, resistente e de tamanho moderado, é indicada para arborização urbana e recuperação de áreas degradadas

Nome vulgar: Jacarandá mimoso, Caroba

Nome científico: Jacaranda brasiliana (Lam.) Pers

Floração: flor de cor Azul, floresce de jul/ago

Altura: $10 \mathrm{~m}$

Descrição: árvore de muita beleza, a madeira da Jacarandá é moderadamente pesada, muito resistente e de longa durabilidade natural. Madeira considerada nobre utilizada no fabrico de mobiliário de luxo, sendo reconhecido seu emprego na construção de pianos. 
Nome vulgar: Cega machado

Nome científico: Physocalymma scaberrimum Pohl,

Floração: julho a agosto

Altura: $5 \mathrm{~m}$ a $10 \mathrm{~m}$

Descrição: Madeira pesada, muito dura ao corte textura grossa, resistente e moderadamente durável. Adequada para uso sob fiação elétrica. Florida, é uma das mais belas árvores brasileiras.

Ainda é necessário ressaltar o papel das palmeiras como o jerivá, excelente fonte de alimento para a avifauna, com também a guariroba, o bacuri todas perfeitamente possíveis de embelezarem as cidades sob o bioma Cerrado, todavia lamentavelmente preteridas por palmeira imperial (Rosystonea oleracea), uma espécie exótica com ligações ao colonialismo português.

Destacar o emprego dos ipês com suas multicores, seja em praças, avenidas ou ainda calçadas, obedecidos os critérios técnicos. Como destacar o mulungu. Pela beleza de seu florescimento e a possibilidade de seu emprego em praças, aleias, parques entre outros empregos. Essa espécie é reconhecida pela ciência como medicinal cujo emprego vem da cultural indígena.

Uma relação de árvores de possibilidades estéticas por porte segue abaixo. Na Tabela 02 árvores com porte 
pequeno, até $10 \mathrm{~m}$; na Tabela 03 as de porte médio, de 10 a $20 \mathrm{~m}$ e na Tabela 4 aquelas de grande porte, acima de $20 \mathrm{~m}$.

Em virtude de influências climáticas é necessário ressaltar que a época do florescimento das espécies pode variar dependendo da região.

Tabela 2- Espécies do Cerrado para arborização urbana de porte pequeno até $10 \mathrm{~m}$.

\begin{tabular}{|l|l|l|l|l|}
\hline Espécie & Nome científico & Porte & Floração & Cor da flor \\
\hline $\begin{array}{l}\text { Aroeira } \\
\text { pimenteira }\end{array}$ & $\begin{array}{l}\text { Schinus } \\
\text { terebinthifolius }\end{array}$ & $\begin{array}{l}5 \\
10 \mathrm{~m}\end{array}$ & Set/jan & Branca \\
\hline Caroba & $\begin{array}{l}\text { Jacaranda } \\
\text { brasiliana }\end{array}$ & $4-10 \mathrm{~m}$ & Jul/set & Azul \\
\hline $\begin{array}{l}\text { Cega } \\
\text { machado }\end{array}$ & $\begin{array}{l}\text { Physocalymma } \\
\text { scaberrimum }\end{array}$ & $\begin{array}{l}5 \\
10 \mathrm{~m}\end{array}$ & Jul/set & $\begin{array}{l}\text { Rosa } \\
\text { intenso }\end{array}$ \\
\hline Marmeleiro & Alibertia edulis & $4-9 \mathrm{~m}$ & Set/dez & Branca \\
\hline $\begin{array}{l}\text { Quares- } \\
\text { meira }\end{array}$ & $\begin{array}{l}\text { Tibouchin } \\
\text { granulosa }\end{array}$ & $\begin{array}{l}9 \\
12 \mathrm{~m}\end{array}$ & Jul/agos & Rosa/roxa \\
\hline Pau terra & $\begin{array}{l}\text { Qualea } \\
\text { grandiflora Mart. }\end{array}$ & $12 \mathrm{~m}$ & $\begin{array}{l}\text { agos a } \\
\text { dez }\end{array}$ & $\begin{array}{l}\text { Amarelo- } \\
\text { ouro }\end{array}$ \\
\hline $\begin{array}{l}\text { Sucupira } \\
\text { branca }\end{array}$ & $\begin{array}{l}\text { Pterodon } \\
\text { pubescens } \\
\text { Benth }\end{array}$ & $\begin{array}{l}8 \\
12 \mathrm{~m}\end{array}$ & Agost/set & $\begin{array}{l}\text { Branca ou } \\
\text { rósea }\end{array}$ \\
\hline $\begin{array}{l}\text { Sucupira } \\
\text { preta }\end{array}$ & $\begin{array}{l}\text { Bowdichia } \\
\text { virgilioides }\end{array}$ & $\begin{array}{l}8 \\
16 \mathrm{~m}\end{array}$ & Agost/set & Azul \\
\hline Ipê amarelo & $\begin{array}{l}\text { Tabebuia } \\
\text { achracea }\end{array}$ & $\begin{array}{l}6- \\
14 \mathrm{~m}\end{array}$ & Jul/set & Amarelo \\
\hline
\end{tabular}

Fonte: As autoras. 
Tabela 3- Espécies do Cerrado para arborização urbana de porte médio de $10 \mathrm{~m}$ a $20 \mathrm{~m}$.

\begin{tabular}{|l|l|l|l|l|}
\hline ESPÉCIE & $\begin{array}{l}\text { NOME } \\
\text { CIENTÍFICO }\end{array}$ & $\begin{array}{l}\text { PORT } \\
\mathrm{E}\end{array}$ & $\begin{array}{l}\text { FLORAÇÃ } \\
\text { O }\end{array}$ & COR DA FLOR \\
\hline $\begin{array}{l}\text { Angico } \\
\text { branco }\end{array}$ & $\begin{array}{l}\text { Anadenanther } \\
\text { a colubrina } \\
\text { (Vell.) Brenan }\end{array}$ & $\begin{array}{l}10- \\
35 \mathrm{~m}\end{array}$ & Set/dez & Branca \\
\hline Faveiro & $\begin{array}{l}\text { Dimorphandra } \\
\text { mollis }\end{array}$ & Jan/jul & Amarela \\
\hline $\begin{array}{l}\text { Ipê } \\
\text { branco }\end{array}$ & Tabebuia sp & $17 \mathrm{~m}$ & Agos/set & Branco \\
\hline $\begin{array}{l}\text { Jacarand } \\
\text { á mimoso }\end{array}$ & $\begin{array}{l}\text { Jacarandá } \\
\text { mimosoefolia }\end{array}$ & $15 \mathrm{~m}$ & Agos/nov & Azulado lilás \\
\hline Mulungu & $\begin{array}{l}\text { Erythrina } \\
\text { mulungu Mart. } \\
\text { ex Benth. }\end{array}$ & $\begin{array}{l}10 \mathrm{a} \\
17 \mathrm{~m}\end{array}$ & jul/set & $\begin{array}{l}\text { Laranja/vermelh } \\
\text { a }\end{array}$ \\
\hline
\end{tabular}

Fonte: As autoras.

Tabela 4- Espécies do Cerrado para arborização urbana de porte grande acima de $20 \mathrm{~m}$.

\begin{tabular}{|l|l|l|l|l|}
\hline $\begin{array}{l}\text { ESPÉCI } \\
\text { E }\end{array}$ & $\begin{array}{l}\text { NOME } \\
\text { CIENTÍFICO }\end{array}$ & $\begin{array}{l}\text { PORT } \\
\mathrm{E}\end{array}$ & $\begin{array}{l}\text { FLORAÇÃ } \\
\text { O }\end{array}$ & COR DA FLOR \\
\hline Copaiba & $\begin{array}{l}\text { Copaifera } \\
\text { langsdorffii }\end{array}$ & $15-35$ & dez & Branca \\
\hline Jatobá & $\begin{array}{l}\text { Hymenaea } \\
\text { stigococarpa }\end{array}$ & $\begin{array}{l}\text { Até } \\
40 \mathrm{~m}\end{array}$ & mar/jul & Cremes/brancas \\
\hline Jenipapo & $\begin{array}{l}\text { Genipa } \\
\text { americana }\end{array}$ & $10-35$ & nov & $\begin{array}{l}\text { Brancas/amarela } \\
\text { s }\end{array}$ \\
\hline Pau ferro & $\begin{array}{l}\text { Caesalpinia } \\
\text { férrea var } \\
\text { ferrea }\end{array}$ & $\begin{array}{l}20 \mathrm{a} \\
30 \mathrm{~m}\end{array}$ & Verao & $\begin{array}{l}\text { Amarelas } \\
\text { pequenas }\end{array}$ \\
\hline Pau terra & $\begin{array}{l}\text { Qualea } \\
\text { grandiflora } \\
\text { Mart. }\end{array}$ & $\begin{array}{l}8- \\
20 \mathrm{~m}\end{array}$ & agos a dez & Amarelo-ouro \\
\hline Peroba & Aspidosperm & $15 \mathrm{a}$ & Out/nov & branco- \\
\hline
\end{tabular}




\begin{tabular}{|l|l|l|l|l|}
\hline rosa & a polyneuron & $25 \mathrm{~m}$ & & $\begin{array}{l}\text { amareladas a } \\
\text { creme }\end{array}$ \\
\hline Tamboril & $\begin{array}{l}\text { Enterolobium } \\
\text { maximum }\end{array}$ & $\begin{array}{l}20- \\
35 \mathrm{~m}\end{array}$ & jun & Brancas \\
\hline Ipê rosa & Tabebuia $s p$ & $\begin{array}{l}20- \\
30 \mathrm{~m}\end{array}$ & Jul/out & Rosa \\
\hline
\end{tabular}

Fonte: As autoras. 


\section{CAPÍTULO 05}

\section{OUTRAS FORMAS DE APROVEITAMENTO ECÔMICA E AMBIENTALMENTE SUSTENTÁVEIS}

Entre muitas outras atividades sustentáveis que contribuem para salvaguardar o Cerrado destacam-se a Criação de Animais Silvestres e a Apicultura. Atividades do ramo da zootecnia brevemente descritas neste ensaio.

\subsection{Criação de animais silvestres em cativeiro}

Comer carne de caça é um hábito histórico dos seres humanos. Criá-los pode vir a ser um costume. E, dessa maneira contribuir para que não sejam extintas além de auxiliar na preservação/conservação de seu habitat natural.

A criação de animais silvestres em cativeiro é uma alternativa de fonte de renda para o produtor rural, que pode ser trabalhada paralelamente a outras atividades. Contribui para que as espécies criadas não corram o risco de extinção e assim sendo trata-se de uma atividade sustentável que favorece a conservação dos Cerrados. Alguns animais são fáceis de serem criados em cativeiro e possuem consumo cultural e por isso mesmo mercado garantido como a paca, 
a capivara e a ema, o equivalente ecológico da avestruz, A carne de animais silvestre alcança valores consideráveis a depender do local de comercialização ou de consumo.

Essa atividade é um ramo da veterinária/zootecnia merecendo mais estudos e divulgação. De acordo com a lei $\mathrm{n}^{\circ}$ 5.197, de 3 de janeiro de 1967 entende-se por fauna silvestre "os animais de quaisquer espécies, em qualquer fase do seu desenvolvimento e que vivem naturalmente fora do cativeiro, constituindo a fauna silvestre, bem como seus ninhos, abrigos e criadouros naturais são propriedades do Estado, sendo proibida a sua utilização, perseguição, destruição, caça ou apanha".

Essa atividade deve atender ao que dispõe a Instrução Normativa IBAMA no 07, de 30 de abril de 2015 que institui e normatiza as categorias de uso e manejo da fauna silvestre em cativeiro, e define, no âmbito do IBAMA, os procedimentos que fornecem autorização para as categorias estabelecidas.

\subsection{APICULTURA - Renda e Preservação Ambiental}

Apicultura é a ciência, ou arte, da criação de abelhas com ferrão, Apis melífera. Numa colmeia são produzidos além do mel, o pólen, fonte de proteína; a geleia 
real um alimento nobre; a cera de múltiplas aplicações; a própolis um antibiótico natural e a apitoxina, essa última pouco conhecida é o veneno das abelhas. Terapeuticamente a apitoxina pode ser usada para minimizar casos de artrite, reumatismo e hipertensão.

Contudo o principal papel que as abelhas desempenham na natureza é a polinização de plantas. $\mathrm{Na}$ ausência delas diversas espécies do Cerrado como entre tantos o araticum, a aroeira e a cervejinha do Cerrado. Ainda muitas de exploração econômica como maçã (Malus doméstica), pera (Pyrus communis), abóbora (Curcubita spp.), acerola (Malpighia emarginata), castanha do Pará (Bertholletia excelsa), cupuaçu (Theobroma grandiflorum), maracujá (Passiflora edulis), melancia (Citrullus lanatus), melão (Cucumis melo), olerícolas, pastagem entre outras estariam comprometidas.

A produção de mel não só é com fins alimentares, mas também terapêuticos como exemplo o mel das abelhas jataí é terapêutico e seu valor de venda é superior a do mel de abelhas europeias africanizadas, o mais comum.

A criação de abelhas sem ferrão, nativas, é denominada de meliponicultura é outra área que merece atenção em virtude de contribuir na preservação destas espécies como ainda garantir a reprodução das espécies 
que delas pendem no processo reprodutivo. Como ainda obter renda aos produtores com a venda do mel ou por vender famílias de abelhas nativas.

\subsection{IMPLANTAÇÃO DO APIÁRIO - Simples e barato}

Não são necessárias grandes estruturas e o custo de produção é barato e o investimento inicial pode ser praticamente pago no primeiro ano de produção. Como o manejo é simples pode ser conduzido em pequenas propriedades com mão de obra familiar. As áreas podem ser aquelas impróprias para a agricultura ou pecuária desde que haja flora apícola na região.

É necessário que o produtor não seja alérgico ao veneno das abelhas e a instalação estar distante no mínimo 200m de estradas e lavouras e edificações.

A criação de abelhas acompanha a história da humanidade. $O$ mel também é citado em diversas passagens do Antigo Testamento e Novo Testamento, sendo mencionado em alguns salmos. A mais conhecida citação é em Mateus 3,4: As roupas de João eram feitas de pelos de camelo, e ele usava um cinto de couro na cintura. O seu alimento era gafanhotos e mel silvestre". 


\subsection{Para não concluir}

A finalidade primeira deste estudo é despertar o interesse sobre o patrimônio natural do bioma destacando as possibilidades de aproveitamento como caminho para a preservação/conservação do Cerrado. Um bioma endêmico a nível planetário e exclusivamente brasileiro. Sua extinção será para sempre

Foram elencadas exclusivamente atividades que associam proteção com geração de renda, de fácil condução e utilizando técnicas ao alcance de qualquer pessoa desde que devidamente orientada por um profissional qualificado. Muitas outras existem.

Da flora com incontáveis espécies cinco dezenas constam neste documento. Uma amostra das muitas possíveis de serem sustentavelmente aproveitadas. Ressalte-se que seu potencial madeireiro não foi abordado. 


\section{BIBLIOGRAFIA CONSULTADA E RECOMENDADA}

ALMEIDA, S. P.; PROENÇA, C. E. B.; et alli. Cerrado: espécies vegetais úteis. Planaltina, DF: EMBRAPA, 1998.

ALTIERI, Miguel A. Agroecologia: as bases científicas da agricultura alternativa. 2.ed. Rio de Janeiro: APTA/FASE, 1999. $240 \mathrm{p}$.

ALTIERI, Miguel A. Agroecologia: a dinâmica produtiva da agricultura sustentável. 2. ed. Porto Alegre: Ed. Universidade/ UFRGS, 2000. 108 p.

AVIDOS, M. F. D. \& FERREIRA, L. T. Frutos dos Cerrados: preservação gera muitos frutos. Biotecnologia Ciência \& Desenvolvimento, p. $36-412003$.

BONILLA, José A. Fundamentos da agricultura ecológica sobrevivência e qualidade de vida. São Paulo: Nobel, 1992.

CAPORAL, F. R.; COSTABEBER, J. A. Agroecologia Enfoque científico e estratégico para apoiar 0 desenvolvimento rural sustentável. Porto Alegre: EMATER/RS-ASCAR junho de 2002, $48 \mathrm{p}$

CNCFlora. Butia capitata in Lista Vermelha da flora brasileira versão 2012.2 Centro Nacional de Conservação da Flora. Disponível em <http://cncflora.jbrj.gov.br/portal/ptbr/profile/Butia capitata>. Acesso em 17 de agosto 2021.

DIEGUES, A.C. \& ARRUDA, R.S.V. (orgs). Saberes tradicionais e biodiversidade no Brasil. Brasília: Ministério do Meio Ambiente, 176p., 2001. 
EITEN, G. Vegetação do Cerrado. In: PINTO, M.N. Cerrado caracterização, ocupação e perspectiva. Brasília: UNB, p.965, 1990. $657 \mathrm{p}$.

FERREIRA, M.B. Frutos comestíveis nativos do Distrito Federal - IV. Cerrado, v.7, n.30, p.15-21, 1975.

FILGUEIRAS, T.S., PEREIRA, B.A. Flora do Distrito Federal. In: PINTO, M.N. Cerrado caracterização e ocupação e perspectivas. Brasília: UnB, p. 331-338, 1990. p.657.

GLIESSMAN, Stephen R.; Agroecologia: processos ecológicos em agricultura sustentável, $2^{\mathrm{a}} \mathrm{ed}$. - Porto Alegre: Ed. Universidade/UFRGS, 2001.

GOMES, V., CARNEVALLI, N.E.D. FERREIRA, M.B., Frutos nativos e exóticos apreciados pelos pássarosHamelia Patens Jacq. Cerrado, v.24, p.9-11, 1974.

GOODLAND, R., FERRI, M. G. Ecologia do Cerrado São Paulo: EDUSP/ Itatiaia, 1979. 193p.

HERINGER, E.P. Dendrologia IX: Gênero qualea:pau-terra, jacaré, umirirama, quaruba, ariana. Cerrado, v.6, n.25, p.2026, 1974.

HERINGER, E.P., FERREIRA, M.B. Dendrologia: gênero hymenaea, jatobás, jataís, jutais etc. Cerrado, v.7, n.27, p.27-32, 1975.

HERINGER, E.P. BARROSO, G.M. RIZZO, J.A., RIZZINI, C.T., A flora do Cerrado. In: IV Simpósio sobre Cerrado, Anais... São Paulo: Itatiaia, 1977. p. 211-231.

JOLY, A.B. Conheça a vegetação brasileira. São Paulo: USP / Polígono, 1970. 
LIMA, B. C. A Flora do Cerrado. In Curso de Atualização em Tecnologia e Manejo de Solos sob Cerrado. Goiânia, E.A./UFG, 1981. Mimeografado

LORENZI, H. Árvores brasileiras: manual de identificação e cultivo de plantas arbóreas nativas do Brasil. 5. ed. Nova Odessa: Plantarum, 2008. v.1.

MAROUELLI, R. P. O desenvolvimento sustentável da agricultura no Cerrado brasileiro. 54 f. Monografia (Especialização Lato Sensu) - ISEA-FGV, Brasília, 2003.

MATTEUCCI, M.B.A.; GUIMARÃES, N.N.R.; TIVERON FILHO, D.; SANTOS, C. A flora dos Cerrados e suas formas de aproveitamento. Anais...Escola Agronomia e Veterinária 25 (1): 13-30, 1995.

MILANO, M.S. A cidade, os espaços abertos e a vegetação. Anais do $1^{\circ}$ Congresso Brasileiro sobre Arborização Urbana. 1992. Vitória. Sociedade Brasileira Arborização Urbana. 1992. Vo1.1. p 3-14

MOLLISON, B. \& SLAY, R.M. Introdução à Permacultura. Brasília: MA/SDR/PNFC,1998.204p.

MOLLISON, B. \& HOLMGREN, D. Permacultura Um.: Uma Agricultura Permanente nas comunidades em Geral. São Paulo: Ground,1983.149p.

NAZARÉ, R.F. de. Obtenção e aplicação de corantes naturais. In: FARIA, L.J.G. de; COSTA, C.M.L. (Ed.). Tópicos especiais em tecnologia de produtos naturais Belém: Universidade Federal do Pará, 1998. p.56-73. 
OLIVEIRA, Maurício Carvalho de; ALMEIDA, Rodrigo Barroso de. Uso sustentável da terra e insumos a produção agropecuária. Brasília MAPA/SARC/DEPV, 2004. 54p.

PEREIRA, B. A. S. Espécies apícolas da flora da área de proteção ambiental (APA) da Bacia do São Bartolomeu, DF (estudo preliminar). Cadernos_de_geociências. Brasília: IBGE, N.5.

PINTO, M. N. (org.) Cerrado: caracterização, ocupação e Perspectiva. Editora Universidade de Brasília.

PIRES, N.A.M.T. et al. A arborização urbana do município de Goiandira/GO- caracterização qualiquantitativa e propostas de manejo. REVSBAU: Piracicaba, v. 5, n. 3, p. 185-205, 2010.

PLANTAS do NORDESTE: especialmente do Ceará. 3. ed. Mossoró: [s. n.], 1976. (Coleção Mossoroense, v. XLII )

POZO, O. V. C. O pequi (Caryocar brasiliense): uma alternativa para o desenvolvimento sustentável do Cerrado no norte de Minas Gerais. 1997. 100 f. Dissertação (Mestrado) - Universidade Federal de Lavras, Lavras, 1997.

POZO, O. V. C. \& GOMES, M. A. O. O pequi (Caryocar brasiliense): viabilidade sócio-econômica do Cerrado no norte de Minas Gerais. 1997. Caderno de Administração Rural, Lavras. Jul./dez. 1997.

PRIMAVESI, A. M - O Manejo Ecológico do Solo - São Paulo - Nobel, 1988. 549p

RENHE, ISIS RODRIGUES TOLEDO et al. Obtenção de corante natural azul extraído de frutos de jenipapo. Pesquisa 
Agropecuária Brasileira [online]. 2009, v. 44, n. 6 [Acessado 17 Agosto 2021], pp. 649-652. Disponível em: <https://doi.org/10.1590/S0100-204X2009000600015>. Epub 07 Ago 2009. ISSN 1678-3921. https://doi.org/10.1590/S0100-204X2009000600015.

RIBEIRO, J.F. A importância econômica do pequi. Cerrado, v.11, n.36, p.24-26, 1980.

RIZZINI, C.T. A flora do Cerrado - Análise florística das savanas centrais. In: Simpósio sobre Cerrado. Anais... Ed. Blucher, 1971. p. 105-153

RIZZINI, C. T. \& COIMBRA - FILHO, A. F. Ecossistemas Brasileiros. Ed. Index, 1988.

RIZZINI, C. T., MORS, W. B. Botânica econômica brasileira. São Paulo: E.P.U./EDUSP, 1976.

SAWYER, D. et al. Extrativismo vegetal no Cerrado: análise de dados de produção, 1980-1993. Brasília: ISPN/CMBBC. 9p., 1999.

SILVA, J.A., MELO, J.T., ALBINO,J.C.Plantio e aproveitamento alimentar de espécies frutíferas nativas do Cerrado.In: Cong. nac. de bot. ,42,1991,Goiânia. Resumos...Soc. Bot. do Brasil.p.225.

SIQUEIRA, J. C. Plantas medicinais: identificação das espécies dos Cerrados. s. j. Loyola, 1988. 39 p.

- Utilização popular das plantas do Cerrado. s. j. Loyola, 1981. 60 p.

VOGTMAN, H.; WAGNER, R. Agricultura ecológica: teoria \& prática. Porto Alegre, Mercado Aberto, 1987. 168 p. 
ZAMBERLAM, Jurandir; FRONCHETI, Alceu. Agricultura Ecológica: preservação do pequeno agricultor e do meio ambiente. Petrópolis, RJ: Vozes, 2. ed. 2002.

WWW.

http://sistemas.icmbio.gov.br/simrppn/publico/rppn/GO, [Acessado 17 Agosto 2021] 
Agência Brasileira ISBN ISBN: 978-65-995551-7-6 